\section{- Materials science buoyed by
education policy in Ethiopia}

www.mofed.gov.et

$\mathrm{T}$ he Ethnological Museum in Addis Ababa, Ethiopia, has an old, tubestyle television in its lobby. A video runs on a loop that is effectively an audiovisual time capsule from the early 1990s full of Addis cityscapes from various neighborhoods and vantage points. To someone arriving in Addis today, these images would be virtually unrecognizable. In the last few decades, Ethiopia's population has grown swiftly; more and more people have moved from rural to urban areas, and Addis Ababa has become one of the fastest growing cities in Africa.

Ethiopia's government has tried to harness this growth to maximize development. To this end, the Ministry of Finance and Economic Development (MOFED) authored a countrywide strategic document known as the Growth and Transformation Plan (GTP I) with the stated goal of "achieving broadbased, accelerated and sustained economic growth so as to alleviate poverty." Initiated in November of 2010, GTP I builds on the accomplishments of the Plan for Accelerated and Sustained

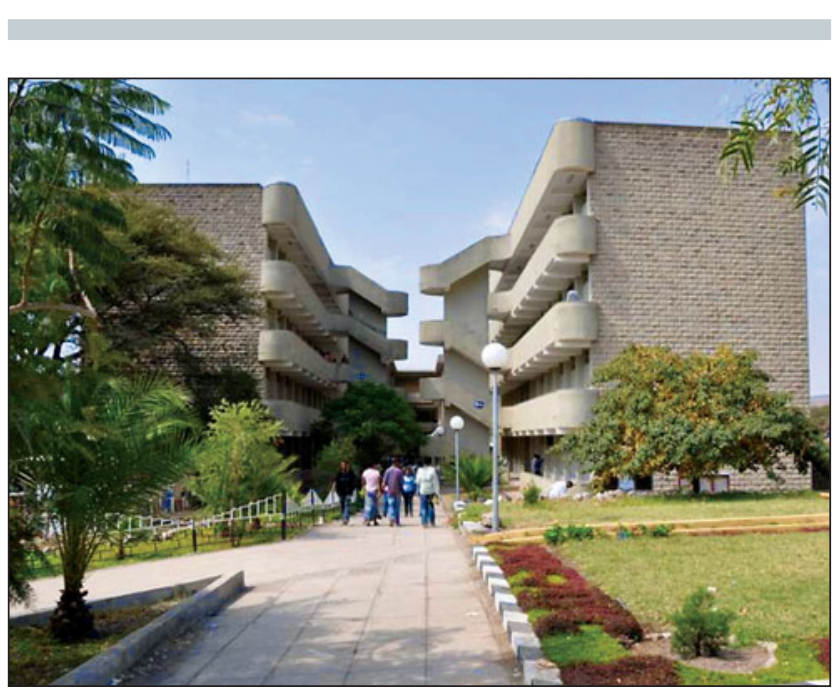

Adama Science and Technology University, Adama, Ethiopia.
Development to End Poverty, which was implemented from 2005-2010.

While the term "materials science" doesn't actually appear in GTP I, the field has significantly benefited from the government's efforts, especially in the university setting. "In the course of GTP I, education was one of the main focus areas," said Kalid Ahmed Seid, Assistant Professor and Department Head at Adama Science and Technology University (ASTU). In fact, during the course of implementing the plan, the government has not just supported materials science programs, it has also birthed them.

In setting education as a priority, GTP I often refers to ensuring "relevance." The plan spells out exactly what "relevance" means when, in its discussion of implementation strategies, it states, "The intake capacity of all universities, especially in science and technology and teacher development programs, will be increased." GTP I also sets out the goal that all new universities "will be furnished with the equipment necessary and encouraged to give priority to science and technology and teacher development programs."

The government has backed its objectives with financial support. "When ASTU requested establishment of the Department of Materials Science Engineering, the government immediately approved. We were able to start the new department in the academic year of 2012/13," said Jang Gyu (John) Lee, Professor and President at ASTU. For Ethiopia, this was uncharted territory. In 2015, Ethiopia's first undergraduate class of materials science students are just a year away from receiving their degrees.

Teketel Yohannes Anshebo, Professor and Department Chair at Addis Ababa University (AAU), had previously broken similar ground when he founded Ethiopia's first graduate program in materials science. He agreed that "GTP I affected materials science and engineering positively." However, he conceded that the impact has been limited. "As the MSE program is in its infant stage, the effect is not that much, mainly because of the program, not because of GTP." In fact, established in 2008, the graduate program at AAU is just a few years older than ASTU's undergraduate equivalent. Currently, the program offers a master's degree, and has plans to add a $\mathrm{PhD}$ program.

The field of materials science still has a lot of room to grow in Ethiopia, and it will have ample opportunity as part of the country's development priorities. According to Lee, Ethiopia has traditionally exported raw materials and imported manufactured goods, with the manufacturing sector only accounting for about $5 \%$ of the GDP. The government aims to change this. "Materials for secondary manufacturing industries and service industries are planned to be produced in Ethiopia. For example, cement factories are encouraged to produce the materials necessary for construction businesses," Lee said.

The budding MSE programs will be crucial to this sector. "Skilled and confident graduates in ceramics, metallurgy, semiconductors, polymers, and so on are the key for the technology transfer and adaptation in the short term and development of indigenous technology in the long term," said Seid.

With GTP I now in its final year, the MOFED has already begun work on GTP II. The professors expect science and technology to feature prominently again. "Higher officials who visited our department have pledged to support the department in any way they can," Seid said. "I am very much optimistic that we will see many positives and [much] progress in ASTU." 
Faculty and research staff at AAU are similarly anticipating GTP II, where Anshebo sits on the Strategic Planning Committee. He said, "The focus area of GTP II will be a major source for the strategic plan to be prepared." He hopes to roll out the $\mathrm{PhD}$ program. The University has already approved the curriculum, and now
Anshebo is just awaiting a budget.

GTP I helped the materials science community get its footing. Now, the scientists are counting on the continued support of the country's leadership. According to Lee, GTP II must approach materials science as "an essential area to develop and improve in Ethiopia." As programs grow and students graduate and research progresses, materials science will produce the knowledge and materials that will develop and improve Ethiopia in return. And the video of Addis Ababa cityscapes at the Ethnological Museum will become increasingly unrecognizable.

Ben Pelhan
US-China Clean Energy Research Center issues solicitation to address the energy-water nexus www.us-china-cerc.org

$\mathrm{T}_{\mathrm{i}}$ he US Department of Energy (DOE) issued a $\$ 12.5$ million Funding Opportunity Announcement (FOA) for a new technical track under the US-China Clean Energy Research Center (CERC) that addresses water-related aspects of energy production and use. The solicitation calls for the formation of a US-based consortium to work with Chinese counterparts to bolster collaborative efforts to help ensure energy, water, and environmental security and to combat climate change. The consortium will be funded with $\$ 12.5$ million DOE support and $\$ 12.5$ million recipient cost share for a total of \$25 million over the five-year period of performance.

"Water resource scarcity, variability, and uncertainty are impacting energy systems in the [United States] and China," said Secretary Ernest Moniz. "Increasing collaboration through the CERC engages the technical resources of both countries, opening opportunities for researchers and industrial partners to address our common challenges in the energy-water nexus. By leveraging science, technology and innovation, we can ensure our collective energy and water security."

This US investment will be matched by an equivalent effort in China, bringing the total bilateral investment to $\$ 50$ million. The new energy-water track was initially announced in November 2014, when President Barack Obama and Chinese President Xi Jinping renewed their commitment to CERC with $\$ 200$ million in total funding over five years. In addition to expanding work under CERC by $\$ 50$ million for research in energy and water, the announcement in November extends ongoing collaborative efforts to
2020, adding $\$ 150$ million to continue initiatives already under way. These focus on the development and deployment of clean vehicles, building energy efficiency, and advanced coal technologies for carbon capture, utilization, and sequestration.

This FOA also seeks to transform how water is used in energy production and electricity generation, while improving water quality and availability for a diverse range of human applications. It builds on the contents of The Water-Energy Nexus: Challenge and Opportunities, which DOE issued in June 2014.

Topics covered in the FOA include water use reduction at thermoelectric plants; treatment and management of nontraditional waters; improving sustainable hydropower design and operation; climate impact modeling, methods, and scenarios to support improved understanding of energy and water systems; and data and analysis to inform planning, policy, and other decisions.
Bernard Bigot appointed as new ITER Director-General www.iter.org

$\mathrm{D}$ uring a meeting held in Paris on March 5, the International Thermonuclear Experimental Reactor (ITER) Council appointed Bernard Bigot as the next Director-General of the ITER Organization, succeeding Osamu Motojima.

Bigot said, "The whole world needs innovative technologies to ensure a long-term sustainable supply of energy. Magnetic confinement fusion is one of the most promising options. I am deeply honored for the possibility of contributing to the large, international, and ambitious research program that is ITER, which has innovation as its aim. Be assured that I will do my best to meet the expectations of the ITER members." Motojima, appointed Emeritus Director-General of the ITER Organization by Bigot, is leaving ITER with the gratitude of the ITER Council and after having made significant contributions to this international endeavor.
Bigot, a distinguished scientist, was the Chair and CEO of the French Alternative Energies and Atomic Energy Commission, CEA, and was also the High Commissioner for ITER in France before he joined the ITER Organization. Bigot has had a long and distinguished career and a record of close involvement with ITER. He is an experienced senior manager of large programs and projects, a leader capable of finding common ground among ITER members, an excellent communicator, and he is highly respected by the fusion research community, according to the ITER Council. He has taken up his duties as Director-General immediately. $\square$ 